\title{
Analisis Faktor-Faktor yang Mempengaruhi Kinerja Sumberdaya Manusia Menggunakan Metode Diskriptif dan Diskriminan pada Proyek Konstruksi di PT.X
}

\author{
Analysis of Factors Affecting Human Resources Performance Using \\ Descriptive and Discriminant Methods in Construction Projects at PT.X
}

\author{
Mochamad Choerul Anam ${ }^{1}$, Ronny Durrotun Nasihien ${ }^{1}$ \\ ${ }^{1}$ Program Studi Teknik Sipil, Fakultas Teknik, Universitas Narotama, Jln.Arief Rachman Hakim No 51, \\ Surabaya. Email : ronny.durrotun@narotama.ac.id
}

\begin{abstract}
Abstrak
Kinerja sumber daya manusia menjadi salah satu faktor keunggulan dari suatu perusahaan. Dengan mengetahui faktor - faktor yang mempengaruhi kinerja sumber daya manusia, maka diharapkan bisa memperbaiki kinerja sumber daya manusia oleh perusahaan sehingga bisa diciptakan kondisi dan lingkunganyang memungkinkan kinerja perusahaan menjadi lebih baik: Karakteristik yang diambil adalah karywan yang terdapat pada suatu proyek konstruksi.

Tujuan dari penelitian ini adalah untuk mengetahui faktor yang paling berpengaruh terhadap kinerja sumber daya manusia dan seberapa besar pengaruh faktor-faktor tersebut. Sebagai obyekpenelitian diamhil salah satu perusahaan jasa konstruksi

PT. X yang berdomisili di Surabaya, dengan data - data daftar prosedur PT.X, daftar pengalaman kerja karyawan PT. X dan Basil kuisioner. Faktor yang memepengaruhi kinerja terbagi alas 2 bagian yaihl: faktor internal dan faktor ekstemal.

Dari hasil penelitian yang dilalcukan menunjukkan bahwa factor yang paling berpengaruh dalam kinerja sumber daya manusia poda proyek konstruksi adalah faktor disiplin diri dengan nilai mean 3,61. Faktor internal adalah faktor yangpaling berpengaruh dalam kinerja sumber daya manusia pada proyek konstruksi dengan nilai mean 3,53. Sedangkan berdasarkan aspek demografi faktor yang berpengaruh terdapat variasi dalam hasilnya. Sehingga dengan mememiliki aspek usaha menunjukkan kemampuan diri, disiplin, dan kemampuan berkomunikasi pada suatu perusahaan diharapkan dapat meningkatkan kinerja perusahaan dalam pencapaian tujuan.
\end{abstract}

Kata Kunci: kinerja, faktor internal, faktor eksternal, sumberdaya manusia. 


\begin{abstract}
The performance of human resources is one of the factors of excellence of a company. By understanding the factors that influence the performance of human resources, it is expected to improve the performance of human resources by the company so that conditions and environment can be created that enable the company's performance to be better: Characteristics taken are employees who are involved in a construction project.

The purpose of this study is to find out the factors that most influence the performance of human resources and how much influence these factors have. As an object of research, one of the company's construction services is agreed

PT. X which is domiciled in Surabaya, with the list of PT.X procedure data, a list of PT. X and Basil questionnaire. The factor that influences performance is divided into two parts: internal factors and external factors.

From the results of the research carried out, it was shown that the most influential factor in the performance of the human resource of construction projects was the self-discipline factor with a mean of 3.61. Internal factors are the most influential factors in the performance of human resources in construction projects with a mean of 3.53. While based on the demographic aspects of the factors that influence there are variations in the results. So that by considering the business aspects of showing self-ability, discipline, and communication skills in a company, it is expected to improve the company's performance in achieving goals.
\end{abstract}

Keywords: performance, internal factors, external factors, human resources.

\section{PENDAHULUAN}

Semakin dekatnya pasar global akan membawa imbas yang dalam dan luas dampaknya dalam sektor industri jasa konstruksi. Dalam industri jasa konstruksi disamping kecanggihan system dan teknologi, hal yang terpenting adalah sumber daya manusia dimana dimensi inimerupakan bagian terpenting dari kinerja sebuah perusahaan jasa konstruksi. Dengancepatnya perubahan dan kemudahan fasilitas dan layanan yang berkembang sekarang membawa dampak makin kompleknya keinginan dan motivasi manusia. Mengetahui faktor - faktor yang mempengaruhi kinerja para pegawai akan sangat membantu sekalidalam upaya meningkatkan kinerja darisuatuperusahaan jasa konstruksi.

Mengembangkan sumber daya manusia dalam industri jasa konstruksi merupakan salah satu upaya strategis yang harus dilakukan oleh perusahaan jasa konstruksi dalam meningkatkan kinerja sumber daya manusia seiring dengan perkembangan ilmu pengetahuan dan teknologi, maka pengembangan sumber daya manusia tidak boleh berhenti tetapi harus. selalu dikembangkankan sesuai dengan kebutuhan pasar. Dengan adanya pengembangan sumber daya manusia ini diharapkan dapat mengurangi inefisiensi yang sering terjadi pada pengerjaan proyek konstruksi yang berakibat timbulnya biaya tinggi yang sangat mempengaruhi persaingan dalam industri jasa konstruksi. Pengembangan sumber daya manusia

PT. X yang bergerak di bidangjasa konstruksi sejak tahun 1980, sebagai hasil pemekaran dari proyek induk pengembangan wilayah sungai kali brantas. Perusahaan yang bergerak pada industri jasa pelaksanaan kontruksi atauu yang disebut kontraktor. Dalam bidang ini perusahaan mengambil segmen pasar utama di bidang bangunan air. Kegiatan usaha perusahaan dilakukan melalui persaingan bebas yang sehat, dengan menerapkan prinsip - prinsip Good Corporate Governance dan etika bisnis yang berlaku. Pada saat ini perusahaan mempunyai 2 kantor devisi, 4 kantor devisi Regional, 4 kantor cabang dan 3 pabrik beton. PT. $\mathrm{X}$ dijadikan obyek penelitian karena perusahaan ini telah mengembangkan dan melatih sumber daya manusia yang ada dengan menerapkan sistem manajemen mutu yang menghasilkan tenaga tenaga yang terampil dan kompeten untuk memberikan pelayanan terbaik kepada penggunajasa konstruksi. 


\section{Tujuan Penelitian}

Tujuan dalam tugas akhir ini adalah :

1. Meneliti faktor apakah yang paling berpengaruh terhadap kinerja sumber daya manusia pada suatu proyek konstruksi.

2. Meneliti seberapa besar pengaruh faktorfaktor tersebut.

\section{Manfaat Penelitian}

Dari penelitian ini, manfaat yang diharapkan adalah sebagai berikut :

Dengan mengetahui faktor yang paling berpengaruh terhadap kinerja sumber daya manusia pada proyek konstruksi dan seberapa besar pengaruhnya diharapkan bisa membantu perusahaan memperbaiki atau mendesain ulang sistem, manajemen, dan administrasi perusahaan agar bisamenghasilkan kinerja individu yang optimal sehingga dapat meningkatkan kinerja dan keunggulan bersaing perusahaan tersebut.

\section{TINJAUAN PUSTAKA \\ Diskripsi Teori}

Dalamsebuah perusahaan jasa konstruksi dituntut kinerjasumber dayamanusia yang unggul dalam menghadapi kompetisi yang semakin ketat dalam industri jasa konstruksi. Untuk mewujudkan kinerja sumber daya manusia yang unggul, harus diketahui terlebih dahulu faktor - faktor yang mempengaruhi kinerja sumber daya manusia pada suatu perusahaan jasa konstruksi terutama yang berada pada proyek konstruksi. Adabeberapa pendapat yang merumuskan tentang Faktor - faktor yang mempengaruhi pencapaian kinerja sumber daya manusia, antara lain :

1. Faktor yang memepengaruhi pencapaian kinerja adalah kernampuan (ability) dan faktor motivasi (motivation)

2. Faktor- faktor yang menentukan tingkat kinerja seorang karyawan yaitu faktor internal dan faktor eksternal

\section{Definis Kinerja}

Kinerja merupakan topik yang akan dibahas faktor - faktor yang mempengaruhinya Ada beberapa definisi tentang kinerja :

Kinerja didefinisikan : sesuatu yang dicapai kemampuankerja, prestasi yang diperlihatkan (Kamus besarbahasa indonesia).
Pengertian kinerja adalah hasil kerja secara kualitas dan kuantitas yang dicapai oleh seorang pegawai dalam melaksanakan tugasnya sesuai dengan tanggung jawab yang diberikan kepadanya. (Keith Davis,1964:484).

Kinerja adalah apayang individu atauorganisasi kerjakan (Ilgenand Scheneider, 1991:73).

Kinerja adalah apa yang organisasi sewa untuk melakukan sesuatu dan dengan baik. Kinerja bukan konsekuensi dari hasil tindakan, tetapitindakan itu sendiri. Kinerja berisidengan tujuan yang relevan langsung dengantindakan dan berada dalam kendali individu tak memandang apakah mereka kognitif motor atau interpersonal. (Campbell, 1993:40).

Kinerja adalah tindakan yang terdiri daribanyak komponen, tidakberupa suatu kejadian atau sebuah hasil yang terjadi dalam satu periode waktu.(Lioyd Bird, 1989:3).

\section{Faktor Internal}

Didefinisikan sebagi hubungan langsung antara pekerja dan tugas biasanya dari inisiatif pribadi. Rasa harga diri, selesainya tugas, tantangan dan kompetensi didapat dari kinerja basil pekerjaan seseorang sebagai misal partisipasi, sering lebih dihubungkan dengan sifat - sifat individu, kemampuan danupaya. Faktor internal meliputi:

1. Usaha Menunjukkan Kemampuan Diri

2.. Disiplin

3. Kemampuan Berkomunikasi

4. Media Saluran Komunikasi

\subsection{Faktor eksnternal}

Faktor yang diambil darilingkungan kerjadalam hubungannya terhadapsebuah tugas. Dan biasanya berbentuk gaji, fasilitas perusahaan, kebijakan perusahaan dan jenis -jenis supervisi (GaryJohns, 1997:161). Faktor eksternal meliputi:

1. Penguasaan Tugas

2. Penguasaan Tugas Tambahan/ Pekerjaan tambahan

3. Manajemen/ Administrasi

4. Kepemimpinan

5. Kerja Tim dan Kinerja Kelompok

6. Umpan Balik 


\section{Penilaian Kinerja}

Penilaian kinerja pegawai dikenal dengan istilah "Performance rating, performance apprasial, personnel assessment, employee evaluation, merit rating, efficiency rating, service rating". Leon C. Meggison (1981:310) mengemukakan bahwa performance apprasial adalah suatu proses yang digunakan majikan untuk menentukan apakah seorang pegawai rnelakukan pekerjaannya sesuai dengan yang dimaksudkan.

Andrew E.Sikula (1981:205) menjelaskan bahwa penilaian pegawai merupakan evaluasi yang sistematis dari pekerjaan pegawai dan potensi yang dapat dikembangkan. Penilaian adalah proses penaksiran atau penentuan nilai,kualitasatau status dari objek, orang ataupun sesuatu. Berdasarkan pendapat diatas, penilaian kinerja pegawai adalah suatu proses penilaian prestasi kerja pegawai yang dilakukan pemimpin perusahaan secara sistematik berdasarkan pekerjaan yang ditugaskan kepadanya. Pemimpin perusahaan menilai prestasi kerja pegawai, yaitu atasan pegawai langsung dan atasan tak langsung. Disamping itu pula, kepala bagian personalia berhak pula memberikan penilaian prestasi terhadap semua pegawainya sesuai dengan data yang ada dibagian personalia.

\section{Metode Analisis}

Metode analisis data yang akan digunakan pada penelitian ini

\section{Analisa deskriptif}

Analisa deskriptif bertujuan untuk mendeskripsikan / menggambarkan suatu data dalam variabel. Dengan prosedur deskriptive pada program SPSS 24, maka akan ditampilkan deskriptif statistic berupa nilai minimum, nilai maximum, nilai mean (rata - rata) dan nilai simpangan baku (standard deviasi). Dengan prosedur frequencies padaprogram SPSS 24 maka akan menampilkan deskripsi statistik berupanilai frekuensi, peresentase valid, persentase kumulatif, nilai simpangan baku (standard deviasi), nilai minimum danmaksimum dari setiap variabel serta nilaimean (rata- rata) dengan rumus:

$\mathrm{xn} \quad=$ Data ke $\mathrm{n}$

$$
\mathrm{x}=\frac{\mathrm{x} 1 \mathrm{f} 1+\mathrm{x} 2 . \mathrm{f} 2+\ldots \mathrm{xn} \cdot \mathrm{fn}}{\Sigma \mathrm{f}}
$$

fn $=$ Frekuensidataken

ir $\quad=$ Jumlah frekuensi

Analisa diskriminan

Prosedur diskriminan akan mengidentifikasi suatu aspek, mengelompokkan tiap aspek kedalam dua atau lebih kelompok berdasar pada kriteria sejumlah variable bebas dan kemudian menganalisis perbedaan pada kelompok tersebut.

\section{METODE}

Dalam penelitian ini dilakukan metode non-random sampling, dimana anggota populasi tak diberi peluang yang dapat dihitung untuk dipilih menjadi anggota sample. Anggota sampel dipilih berdasarkan pertimbangan tertentu dan hams representative hal ini dikarenakan Ciri - ciri pada sampel tersebut harus di kenal baik yaitu orang -orang yang berpengaruh terhadap kinerja sumber daya manusia yang dapat meningkatkan produktifitas perkembangan perusahaan jasa kontruksi tersebut. Penentuan sampel non acak dilakukan karena tak ada daftar anggota populasi. Untuk keperluan pengelolahan data penulis mengambil 100 responden dimana responden tersebut diminta untuk mengisi kuisioner. Dengan menggunak.an rumus ini bisa dihitung jumlah responden

\section{HASIL DAN PEMBAHASAN \\ Analisa Deskriptif Ditinjau Dari Aspek Demografi Populasi}

Aspek Jenis Kelamin ada sejumlah 100 orang, terdiri dari 79 orang berjenis kelamin pria dengan persentase $79 \%$, dan 21 orang wanita dengan persentase $21 \%$. Aspek Posisi I Pekerjaan dari 100 responden, 5 orang bekerja sebagai site manager dengan persentase $5 \%, 5$ orang bekerja sebagai administrasi dengan persentase $5 \%, 4$ orang bekerja sebagai surveyor dengan persentase 4 $\%, 10$ orang bekerja sebagai pelaksana dengan persentase $10 \%, 10$ orang bekerja sebagai logistik dengan persentase $10 \%, 6$ orang bekerja sebagai operator dengan persentase $6 \%, 7$ orang bekerja sebagai mandor dengan persentase $7 \%, 5$ orang bekerja sebagai keamanan dengan persentase 5 $\%$,dan 1 sisanya 48 orang bekerja sebagai pekerja dengan persentase $48 \%$. Aspek Umur dari 100 orang responden, tidak ada responden yang berumur $<20$ tahun, 11 orang yang berumur 20-25 tahun dengan persentase $11 \%, 36$ orang yang herumur 25-30 tahun dengan persentase $36 \%$, 32 orang yang herumur 30-35 tahun dengan persentase $32 \%, 12$ orang yang berumur $35-40$ tahun dengan persentase $12 \%$, 9 orang yang berumur $>40$ tahun dengan persentase $9 \%$. Aspek Pendidikan 46 orang berpendidikan SMA dan sederajat dengan persentase $46 \%, \quad 15$ orang berpendidikan S 1 dengan persentase $15 \%, 1$ orang berpendidikan S2 dengan persentase $1 \%$, 12 orang berpendidikan Diploma (03) dengan persentase $12 \%, 17$ orang. berpendidikan SMP 
dengan persentase $17 \%$, dan 9 orang berpendidikan SD dengan persentase 9\%. Aspek Status Pegawai data status pegawai dari responden yang berjumlah 100 orang, 34 orang pegawai berstatus pegawai tetap dengan persentase $34 \%$, dan 66 orang pegawai berstatus pegawai kontrak dengan persentase $66 \%$. Aspek Lama Bekerja responden yang berjum.lah 100 orang, 7 orang pegawai lama bekerjanya 1 - 3 tahun dengan persentase $7 \%, 36$ orang pegawai lama bekerjanya 3 - 5 tahun dengan persentase $36 \%$, 57 orang pegawai lama bekerjanya $>5$ tahun dengan persentase $57 \%$.

\section{Analisa Berdasarkan Faktor - Faktor Yang Mempengaruhi Kinerja Sumber Daya Manusia.}

100 responden, maka terlihat bahwa elemen yang berpengaruh dari aspek ini adalah pengalaman kerja (A7) dengan nilai rata-rata 4,02 dan std. deviasinya 0,696, dan elemen yang sedikit pengaruhnya adalah keadaan psikologis (A3) dengan nilai rata - rata 3,12 dan std. deviasinya 0, 795. Secara keseluruhan niali rata - rata dari semua elemen ini 3,58 dengan std. deviasinya 0,340 .

100 responden, terlihat elemen yang berpengaruh adalah kesadaran mematuhi peraturan (BI) dengan nilai rata - rata 3,81 dan std.deviasinya 0,734, sedang elemen yang kurang pengaruhnya adalah menjaga sikap dalam bekerja (B2) dengan nilai rata - rata 3,41 dan std. deviasinya 0,570 . Secara keseluruhan nilai rata - rata dari semua elemen ini (ave 2) adalah 3,61 dan std. deviasi 0,447 .

100 responden, terlihat elemen yang paling berpengaruh adalah arus komunikasi yang lancar (C4) dengan nilai rata - rata 3,62 dan std. deviasi 0,546. Dan elemen yang kurang berpengaruh adalah kemampuan membaca gambar bestek $(\mathrm{Cl})$ dengan nilai rata - rata 3,25 dan std deviasi 1,575. Secara keseluruhan nilai rata - rata dari semua elemen (ave 3) adalah 3,40 dan std. deviasi 0,361 .

100 responden, terlihat elemen yang paling berpengaruh adalah Pengaturan waktu, material dan SDM (D4) dengan nilai rata - rata 3,53 dan std deviasi 0, 745. Dan elemen yang kurang herpengaruh adalah jenis I model pekerjaan (D5) dengan nilai rata - rata 3,04 dan std. deviasi 0,803 . Secara keseluruhan nilai rata - rata dari semua elemen (ave 4) adalah 3,30 dengan std.deviasi 0,393 .

100 responden, terlihat elemen yang paling berpengaruh adalah kepedulian dan pengertian pimpinan (E5) dengan nilai rata - rata 3,50 dan std.deviasi 0,659. Dan elemen yang kurang berpengaruh adalah keputusan I kebijakan pimpinan (ES) dengan nialai rata- rata 3)0 dan std.deviasi 0,732. Secara keseluruhan nilai ratarata dari semua elemen adalah 3,38 dan std.deviasi 0,370 .

100 responden, terlihat elemen yang paling berpengaruh adalah kekompakan I kerjasama tim (F2) dengan nilai rata - rata 4, 15 dan std.deviasi 0,592. Dan elemen yang kurang berpengaruh adalah Pengaruh rekan kerja (Fl) dengan nilai rata - rata 3, 18 dan std.deviasi 0,682. Secara keseluruhan nilai rata - rata dari semua elemen (ave 6) adalah 3,53 dengan std.deviasi 0,333.

100 responden, terlibat elemen yang paling berpengaruh adalah kerja lembur (GI) dengan nilai rata - rata 3,57 dan std.deviasi 0,655. Dan elernen yang kurang berpengaruh adalah pekerjaan diluar pekerjaan utama (G2) dengan nilai rata - rata 3,27 dan std.deviasi 0,941. Secara keseluruhan nilai rata - rata dari semua elemen (ave 7) adalah 3,42 dan std.deviasi 0,626. 100 responden, terlihat elemen yang paling berpengaruh adalah kelengkapan fasilitas penunjang (HS) dengan nilai rata- rata 3,42 dan std.deviasi 0,945. Dan elemen yang kurang berpengaruh adalah posisi/pekerjaan yang ditempati sekarang $(\mathrm{H} 2)$ dengan niali rata- rata 2,88 dan std.deviasi 0,844. Secara keseluruhan nilai rata-rata dari semua elemen (ave 8) adalah 3,09 dan std.deviasi 0,463 .

100 responden, terlihat elemen yang paling berpengaruh adalah I insentif I bonus (II) dengan nilai rata - rata 4,63 dan std.deviasi 0,485 . Dan elemen yang kurang berpengaruh adalah san.ksi (13) dengan nilai rata - rata 2,79 dan std.deviasi 0,743. Secara keseluruhan nilai rata - rata dari semua elemen adalah 3,55 dengan std.deviasi 0,468 .

\section{Analisa Berdasarkan Faktor Internal dan Faktor Eksternal Yang Mempengaruhi Sumber Daya Manusia}

100 responden, terlihat aspek yang paling berpengaruh adalah disiplin diri (ave 2) dengan nilai rata - rata 3,61 dan std.deviasi 0,477. Dan aspek yang kurang berpengaruh adalah kemampuan berkomunikasi (ave 3) dengan nilai rata - rata 3,40 dan std.deviasi 0,361 . Secara keseluruhan nilai rata - rata dari semua elemen adalah 3,53 dengan std.deviasi 0,255.

100 responden, terlihat aspek yang paling berpengaruh adalah umpan balik (ave 9) dengan nilai rata - rata 3,56 dan std.deviasi 0,475 . Dan 
aspek yang kurang berpengaruh adalah manajemen (ave 8) dengan nilai rata-rata 3, 10 dan std.deviasi 0,463 . Secara keseluruhan nilai rata - rata dari semua elemen adalah 3,36 dengan std.deviasi $\quad 0,208$.

\section{Analisa Berdasarkan Aspek Demografi} Aspek Kinerja Berdasar Jenis Kelamin

Aspek Usaha Menunjukkan Kemampuan Diri (ave I)

Mean untuk pria sebesar 3,55 (lampiran 2, hal 91) lebih rendah dari mean wanita sebesar 3,66 (lampiran 2, hat 91). Hal ini berarti aspek usaha menunjukkan kemampuan diri lebih berpengaruh pada wanita. Hal ini disebabkan oleh karena wanita lebih berusaha menunjukkan kemampuan diri dengan menjaga kualitas hasil pekerjaan dan mengembangkan keahliannya dalam bekerja. Anglea sig. 0.20 (lampiran 2, ha! 92) >0.05.

Aspek Disiplin Diri (ave 2)

Mean untuk pria sebesar 3,56 (larnpiran 2, ha! 91) lebih rendah dari mean wanita sebesar 3,76 (lampiran 2, hal 91). Hal ini berarti aspek disiplin diri lebih berpengaruh pada wanita. Hal ini disebabkan oleh karena wanita lebih disiplin dalam hal mematuhi peraturan dan menjaga sikap baik dalam bekerja. Angka sig. 0.08 (lampiran 2, hal 92) >0.05

Aspek Kemampuan Berkomunikasi (ave 3)

Mean untuk pria sebesar 3,37 (lampiran 2, hal 91) lebih rendah dari mean wanita sebesar 3,51 (lampiran 2, hal 91). Hal ini berarti aspek kemampuan. Anglea sig. 0.26 (lampiran 2, hal 92) $>0.05$

Aspek Pekerjaan Tambahan (ave 7)

Mean untuk pria sebesar 3,47 (lampiran 2, hal 91) lebih tinggi dari mean wanita sebesar 3,21 (lampiran 2, hal 91). Hal ini berarti aspek pekerjaan tambahan lebih berpengaruh pada pria. Hal ini disebabkan oleh karena pria lebih mempunyai kemauan untuk menegrjakan pekerjaan diluar pekerjaan utamanyas daripada responden wanita. Anglea sig. 0.09 (lampiran 2, ha! 92) $>0.05$

Aspek Manajemen (ave 8)

Mean untuk pria sebesar 3,01 (lampiran 2, hal 91) lebih rendah dari mean wanita sebesar 3,40 Aspek Umpan Balik (ave 9)

Mean untuk pria sebesar 3,55 (lampiran 2, hal 91) lebih rendah dari mean wanita sebesar 3,56

\section{Aspek Kinerja Berdasar pekerjaan}

Aspek Usaha Menunjukkan Kemampuan Diri (ave 1)

Mean untuk site manager sebesar 3,82, Angka sig. 0.82 (lampiran 2, ha! 95) $>0.05$.

Aspek Disiplin Diri (ave 2)

Mean untuk pelaksana sebesar 4,05. Angka sig. 0.02 (lampiran 2, hal 95) $<0.05$.

Aspek Kemampuan Berkomunikasi (ave 3)

Mean untuk operator sebesar 3,76, Angka sig. 0.04 (lampiran 2, hal 95) $<0.05$

Aspek Penguasaan Tugas (ave 4)

Mean untuk operator sebesar 3,45, Angka sig. 0.56 (lampiran 2, hal 95) $>0.05$

Aspek Kepemimpinan (ave 5)

Mean untuk operator sebesar 3,66 , Angka sig. 0.053 (lampiran 2, hal 95) $>0.05$,

Aspek Kerja Tim (ave 6)

Mean untuk keamanan sebesar 3,65, Angka sig. 0.093 (lampiran 2, hal 95) $>0.05$,

Aspek PekerjaanTambahan (ave 7)

Mean untuk surveyor sebesar 3, 75 , Angka sig. 0,36 (lampiran 2, ha! 95) >0,05

Aspek Manajemen (ave 8)

Mean untuk administrasi sebesar 3,33, Angka sig. 0.74 (lampiran 2, hal 95) $>0.05$,

Aspek Umpan Balik (ave 9)

Mean untuk site manager sebesar 4,20 , Angka sig. 0.00 (lampiran 2, hal 95) $<0.05$,

\section{Aspek Kinerja Berdasar Umur}

Aspek Usaha Menunjukkan Kemampuan Diri (ave 1)

Mean untuk umur $>40$ tahun sebesar 3,66, Angka sig. 0.58 (lampiran 2, hai 98) $>0.05$

Aspek Disiplin Diri (ave 2)

Mean untuk umur 35 - 40 tabun sebesar 3,48 . Angka sig. 0. 764 (lampiran 2, ha! 98) $>0.05$.

Aspek Kemampuan Berkomunikasi (ave 3)

Mean untuk operator sebesar 3,76, Angka sig. 0.75 (lampiran 2, hal 98) $>0.05$.

Aspek Penguasaan Tugas (ave 4)

Mean untuk umur $>40$ tahun sebesar 3,38, Angka sig. 0.62 (lampiran 2, hal 98) >0.05.

Aspek Kepemimpinan (ave 5)

Mean untuk umur 25 - 30 tahun sebesar 3,49, Angka sig. 0.03 (lampiran 2, hal 98) <0.05,

Aspek Kerja Tim (ave 6)

Mean untuk umur 30 - 35 tahun sebesar 3,60, Angka sig. 0.30 (lampiran 2, hal 98) >0.05, Aspek PekerjaanTambahan (ave 7)

Mean untuk umur 25 - 30 tahun sebesar 3,52, Angka sig. 0.64 (lampiran 2, hal 98) >0.05, Aspek Manajemen (ave 8) 
Mean untuk umur 25 - 30 tahun sebesar 3, 12, Angka sig. 0.96 (lampiran 2, ha! 98) >0.05, Aspek Umpan Balik (ave 9)

Mean untuk umur 20 - 25 tahun sebesar 3,82, Angka sig. 0.27 (lampiran 2, hal 98) $>0.05$.

\section{Aspek Kinerja Berdasar Pendidikan}

Aspek Usaha Menunjukkan Kemampuan Diri (ave 1)

Mean untuk S2 sebesar 3, 71, Angka sig. 0.40 (lampiran 2, ha! 101) >0.05,

Aspek Disiplin Diri (ave 2)

Mean untulc SI sebesar 3,93. Angka sig. 0.02 (lampiran 2, hal 101) <0.05.

Aspek Kemampuan Berkomunikasi (ave 3)

Mean untuk S2 sebesar 3,80, Angka sig. 0.43

(lampiran 2, hal 101) $>0.05$.

Aspek Penguasaan Tugas (ave 4)

Mean untuk SMA sebesar 3,40, Angka sig. 0.11

(lampiran 2, hal IOI) $>0,05$.

Aspek Kepemimpinan (ave 5)

Mean untuk S2 sebesar 3,60, Angka sig. 0.04 (lampiran 2, hal 101) <0.05,

Aspek Kerja Tim (ave 6)

Mean untuk D3, STM, SMP, DAN SD sebesar 3,60 , Angka sig. 0.36 (lampiran 2, hal 101) > 0.05 ,

Aspek PekerjaanTambahan (ave 7)

Mean untuk SMA sebesar 3,60 , Angka sig. 0.07 (lampiran 2, hal 101) $>0.05$,

Aspek Manajemen (ave 8)

Mean untuk S2 sebesar 3,50, Angka sig. 0.06 (lampiran 2, hal 101) $>0.05$,

Aspek Umpan Balik (ave 9)

Mean untuk S2 sebesar 4,20, Angka sig. 0.00 (lampiran 2, ha! 101) <0.05.

\section{Aspek Kinerja Berdasar Status Pegawai}

Aspek Usaha Menunjukkan Kemampuan Diri (ave 1)

Mean untuk pegawai tetap sebesar 3,60, Angka sig. 0.621 (lampiran 2, hal 103) $>0.05$,

Aspek Disiplin Diri (ave 2)

Mean untuk pegawai tetap sebesar 3, 76 . Angka sig. 0.01 (lampiran 2, hal 103) $<0.05$.

Aspek Kemampuan Berkomunikasi (ave 3)

Mean untuk pegawai tetap sebesar 3,45 , Angka sig. 0.51 (lampiran 2, ha! 89) $>0.05$.

Aspek Penguasaan Tugas (ave 4)

Mean untuk pegawai kontrak sebesar 3,33 , Angka sig. 0.14 (lampiran 2, hal 103) $>0.05$.

Aspek Kepemimpinan (ave 5)

Mean untuk pegawai kontrak sebesar 3,46, Angka sig. 0.001 (lampiran 2, hal 103) < 0.05 ,

\section{Aspek Kerja Tim (ave 6)}

Mean untuk pegawai kontrak sebesar 3,53, Angka sig. 0.90 (lampiran 2, hal 103) >0.05, Aspek PekerjaanTambahan (ave 7)

Mean untuk pegawai kontrak sebesar 3,44, Angka sig. 0.67 (lampiran 2, hal 103) $>0.05$,

Aspek Manajemen (ave 8)

Mean untuk pegawai tetap sebesar 3,14, Angka sig. 0.51 (lampiran 2, hal 103) $>0.05$,

Aspek Umpan Balik (ave 9)

Mean untuk pegawai tetap sebesar 3,90, Angka sig. 0.00 (lampiran 2, hal 103) $<0.05$,

\section{Aspek Kinerja Berdasar Lama Bekerja}

Aspek Usaha Menunjukkan Kemampuan Diri (ave 1)

Mean untuk > 5 tahun sebesar 3,58 (lampiran 2, hal 104) paling tinggi dibanding lama bekerja yang lain. Hal ini menunjukkan bahwa aspek usaha menunjukkan kemampuan diri lebih berpengaruh pada lama bekerja $>5$ tahun. Hal ini disebabkan oleh karena pekerja dengan lama bekerja > 5 tahun lebih dapat menunjukkan kemampuan diri dengan menjaga lcualitas hasil pekerjaan dan mengernbangkan keahliannya dalam bekerja.

Angka sig. 0.98 (lampiran 2, hal 105) $>0.05$, hal ini menunjukkan tidak ada perbedaan sikap untuk semua jenis lama bekerja terhadap variabel usaha menunjukkan kemampun diri didalam kinerjanya. Atau dapat diartikan aspek.

\section{SIMPULAN}

Setelah melakukan percobaan laboratorium dan analisis terhadap hasil percobaan tersebut dapat disimpulkan :

Dari uraian diatas, dapat disimpulkan beberapa hal sebagai berikut:

Faktor yang paling berpengaruh terhadap kinerja sumber daya manusia pada proyek konstruksi adalah faktor disiplin diri dengan nilai mean 3,61.

Faktor yang paling berpengaruh terhadap kinerja sumber daya manusia pada proyek konstruksi adalah faktor internal dengan nilai mean 3,53

Faktor - faktor yang mempengaruhi kinerja sumber daya manusia berdasar aspek demografi:

\section{a. Aspek kinerja berdasar jenis kelamin}

Usaha menunjukkan kemampuan diri, lebih berpengaruh pada wanita dengan nilai mean 3,66. Disiplin, lebih berpengaruh pada wanita dengan nilai mean 3,76 . 
Kemampuan berkomunikasi, lebih berpengaruh pada wanita dengan nilai mean 3,51.

Penguasaan tugas, lebih berpengaruh pada pria dengan nilai mean 3,31 .

Kepemimpinan, Jebih berpengaru.h pada wanita dengan nilai mean 3,44 .

Kerja tirn, lebih berpengaruh pada responden wanita dengan nilai mean 3,60.

Pekerjaan tambahan, lebih berpengaruh pada pria dengan nilai mean 3,47 .

Manajemen, lebih berpengaruh pada wanita dengan nilai mean 3,40

Umpan balik, lebih berpengaruh pada wanita dengan nilai mean 3,56 .

\section{b. Aspek kinerja berdasar pekerjaan}

Usaha menunjukkan kemampuan diri, lebih berpengaruh pada site manager dengan nilai mean 3,82 .

Disiplin, lebih berpengaruh pada pelaksana dengan nilai mean 4,05.

Kemampuan berkomunikasi, lebih berpengaruh pada operator dengan nilai mean 3,76.

Penguasaan tugas, lebih berpengaruh pada operator dengan nilai mean 3,45 .

Kepemimpinan, lebih berpengaruh pada operator dengan nilai mean 3,66.

Kerja tim, lebih berpengaruh pada keamanan dengan nilai mean 3,65.

Pekerjaan tambahan, lebih berpengaruh pada surveyor dengan nilai mean 3,75 .

Manajemen, lebih berpengaruh pada administrasi dengan nilai mean 3,33.

Umpan balik, lebih 1.,erpengaruh pada site manager dengan nilai mean 4,20

\section{c. Aspek kinerja bersdasar umur}

Usaha menunjukkan kemampuan diri, lebih berpengaruh pada umur $>40$ tahun dengan nilai mean 3,66.

Disiplin, lebih berpengaruh pada umur $20-25$ tahun dengan nilai mean 3,71 .

Kemampuan berkomunikasi, Iebih berpengaruh pada umur 35 - 40 tahun dengan nilai mean 3,48 .

Penguasaan tugas, lebih berpengaruh pada umur $>40$ tahun dengan nilai mean 3,38.

Kepemimpinan, lebih berpengaruh pada umur 25 - 30 tahun tahun dengan nilai mean 3,49 .

Kerja tim, lebih berpengaruh pada umur 30 35 tahun dengan nilai mean 3,60 .

Pekerjaan tambahan, lebih berpengaruh pada umur 25 - 30 tahun dengan nilai mean 3,52.
Manajemen, lebih berpengaruh pada 25 - 30 tahun dengan nilai mean 3,12.

Umpan balik, lebih berpengaruh pada $20-25$ tahun dengan nilai mean 3,82 .

\section{d. Aspek kinerja berdasar pendidikan}

Usaha menunjukkan kemampuan diri, lebih berpengaruh pada S2 dengan nilai mean 3, 71 .

Disiplin, lebih berpengaruh pada SI dengan nilai mean 3,93.

Kemarnpuan berkomunikasi, lebih berpengaruh pada S2 dengan nilai mean 3,80.

Penguasaan tugas, lebih berpengaruh pada SMA dengan nilai mean 3,40 .

Kepemimpinan, lebih berpengaruh pada S2 dengan nilai mean 3,60.

Kerja tim, lebih berpengaruh pada D3,STM, SMP,SD dengan nilai mean 3,60.

Pekerjaan tambahan, lebih berpengaruh pada SMA dengan nilai mean 3,60.

Manajemen, lebih berpengaruh pada S2 dengan nilai mean 3,50 .

Umpan balik, lebih berpengaruh pada S2 dengan nilai mean 4,20 .

\section{e. Aspek kinerja berdasar status pegawai}

Usaha menunjukkan kemampuan diri, lebih berpengaruh pada pegawai tetap dengan nilai mean 3,60.

Disiplin, lebih berpengaruh pada pegawai tetap dengan nilai mean 3,76 .

Kemampuan berkornunikasi, Iebih berpengaruh pada pegawai tetap dengan nilai mean 3,45.

Penguasaan tugas, lebih berpengaruh pada pegawai kontrak dengan nilai mean 3,33.

Kepemimpinan, lebih berpengaruh pada pegawai kontrak dengan nilai mean 3,46.

Kerja tim, lebih berpengaruh pada pegawai kontrak dengan nilai mean 3,53.

Pekerjaan tambahan, lebih berpengaruh pada pegawai kontrak dengan nilai mean 3,44.

Manajemen, lebih berpengaruh pada pegawai tetap dengan nilai mean 3,14 .

Umpan balik, lebih berpengaruh pada pegawai tetap dengan nilai mean 3,90 .

\section{f Aspek kinerja berdasar lama bekerja}

Usaha menunjukkan kernampuan diri, lebih berpengaruh pada lama bekerja $>5$ tahun dengan nilai mean 3,58 .

Disiplin, lebih berpengaruh pada lama bekerja 1

- 3 tahun dengan nilai mean 3,78. 
Kemampuan berkomunikasi, lebih berpengaruh pada lama bekerja 1 - 3 tahun dengan nilai mean 3,65 .

Penguasaan tugas, lebih berpengaruh pada lama bekerja $>5$ tahun dengan nilai mean 3,31.

Kepemimpinan, lebih berpengaruh pada lama bekerja 3 - 5 tahun dengan nilai mean 3, 40 .

Kerja tim, lebih berpengaruh pada lama bekerja $>5$ tahun dengan nilai mean 3,56.

Pekerjaan tambahan, lebih berpengaruh pada lama bekerja 3 - 5 tahun dengan nilai mean 3,51.

Manajemen, lebih berpengaruh pada lama bekerja 1 - 3 tahun dengan nilai mean 3,31.

Umpan balik, lebih berpengaruh pada lama bekerja 1 - 3 tahun dengan nilai mean 3,82.

\section{REFERENSI}

Gary Johns, 1996, Organizational Behavior, fourth edition, Harper Collins College Publisher.

John M.Ivancevich, 1995, Michael Matteson, Organizational Behavior and Management, fourth edition.
A Dale Timpe, 1992, Kinerja, PT. Gramedia Asri Media.

Anwar Prabu Mangkunegara, 2005, ManajemenSamber Daya Manusia Perusahaan, PT. Remaja Rosda Karya Bandung.

Michael Amstrong, 2004, Performance Management, Tugu Yogyakarta.

Istimawan Dipohusodo, 1996, Manajemen Proyek \& Konstruksi, jilid I, Kanisius Yoyakarta.

Wulfram I.Ervianto, 2004, Teori-Aplikasi Manajemen Proyek Konstruksi, Andi Y ogyakarta

Suharsimi Arikunto, 2002, Prosedur Penelitian Suatu Pendekatan Praktek, edisi revisi V, Rineka Cipta.

Mardalis, 2006, Metode Penelitian Suatu Pendekatan Proposal,Bumi Aksara.

Bhuono Agung Nugroho, 2005, Strategi Jitu Memilih Metode Statistik Penelitian

Dengan SPSS, Andi Yogyakarta. 